\title{
Etiology of childhood diarrhoea among under five children and molecular analysis of antibiotic resistance in isolated enteric bacterial pathogens from a tertiary care hospital, Eastern Odisha, India
}

\author{
Sonam S. Moharana ${ }^{1 \dagger}$, Rakesh K. Panda ${ }^{1 \dagger}$, Muktikesh Dash ${ }^{1}$, Nirupama Chayani ${ }^{1}$, Priyanka Bokade²,
}

Sanghamitra Pati ${ }^{2}$ and Debdutta Bhattacharya ${ }^{2^{*}}$ (D)

\begin{abstract}
Background: Although, India has made steady progress in reducing deaths in children younger than 5 years, the proportional mortality accounted by diarrhoeal diseases still remains high. The present hospital based cross sectional study was carried out to understand the prevalence of various bacterial pathogens associated with the diarrhoea cases in under 5 years age group.

Methods: During, 1st September, 2015 to 30th November 2017, all the childhood diarrhoea cases ( $\leq 5 \mathrm{yrs}$ ) of SCB Medical College in Odisha, India were included in the study. Stool samples were collected and processed for the isolation of causative bacterial pathogen and the isolated bacterial pathogens were subjected to antibiotic sensitivity testing, molecular analysis of drug resistance. Clinical and demographic data were collected and analyzed.
\end{abstract}

Results: Three hundred twenty patients were enrolled in the study during the study period from whom 82 bacterial isolates were obtained indicating a proportional causality of $25.6 \%$ for bacterial diarrhoea among children in this region. Entero toxigenic E.coli (ETEC) accounted for majority of the cases and and more than $50 \%$ of the strains were found to be multi-drug resistant (resistant to more than 3 class of antibiotics). More than $50 \%$ of the strains were resistant to current choice of treatment like ciprofloxacin, ofloxacin and ceftriaxone and $2.4 \%$ being resistant to Imipenem. ESBL production was also observed in some of the strains and one isolate harboured the NDM-1 gene. Fluoroquinolone resistance was found to be linked with multiple mutations in the QRDR region followed by PMQR determinants.

Conclusion: The current study, to the best of our knowledge is first of its kind which demonstrated the etiology of bacterial diarrhoea in children less than 5 years old and identified diarrheogenic $E$. coli as the predominant enteropathogen in Odisha. Majority of the isolates being multi-drug resistance calls for a continuous surveillance system in the region which will be helpfulin identifying emerging resistance pattern and for developing suitable intervention stategies.

Keywords: Childhood diarrhoea, Under 5 years, Etiology, E.coli, Multidrug-resistant, Mutation, QRDR, DEC, Surveillance

\footnotetext{
* Correspondence: drdebduta.bhattacharya@yahoo.co.in;

drdebdutta.bhattacharya@yahoo.co.in

tSonam S. Moharana and Rakesh K. Panda contributed equally to this work.

${ }^{2}$ Dept. of Bacteriology \& One Health, ICMR-Regional Medical Research Centre

(Dept. of Health Reserch, Ministry of Health \& Family Welfare, Govt. of India),

Chandrasekharpur, Bhubaneswar 751023, India

Full list of author information is available at the end of the article
}

(c) The Author(s). 2019 Open Access This article is distributed under the terms of the Creative Commons Attribution 4.0 International License (http://creativecommons.org/licenses/by/4.0/), which permits unrestricted use, distribution, and reproduction in any medium, provided you give appropriate credit to the original author(s) and the source, provide a link to the Creative Commons license, and indicate if changes were made. The Creative Commons Public Domain Dedication waiver (http://creativecommons.org/publicdomain/zero/1.0/) applies to the data made available in this article, unless otherwise stated. 


\section{Background}

In developing countries, diarrhoea continues to be one of the major contributing factor for morbidity and mortality among children and ranks 2nd most common cause of death among the group under 5 years of age globally after respiratory illness [1]. Rapid progress has been made by India in reducing deaths in children under 5 years, with total deaths declining from 2.5 to 1.5 million during 2001-2012 [2] which was due to various programs adopted by the government on Immunization and Integrated Management of Childhood illnesses (IMNCI) [3]. However, the proportional mortality due to acute diarrhoeal diseases still remains high.

An estimated 300,000 children die each year in India making diarrhoea as the 3rd major cause of death in children below 5 years of age (MDSC, 2010). National Institute of Cholera and Enteric Disease, Kolkata, (India), reported crude death rate due to diarrhoea in rural India as 9.3 per 1000 populations and $22 \%$ of the total deaths among 0-6 year age due to diarrhoeal disease [4]. The highest percentage of children suffering from diarrhoea belonged to states of Madhya Pradesh, Odisha and Tamil Nadu [5].

Among developing countries across the world, Rotavirus and Escherichia coli are the two most common causes of diarrhoea, whereas Campylobacter spp. is significantly responsible for diarrhoea in developed countries [6]. The most common diarrhoeagenic pathogen include Escherichia coli, Rotavirus, Salmonella spp., Shigella spp., Entamoeba histolytica and enterotoxigenic Bacteroides fragilis, Campylobacter jejuni, Cryptosporidium spp [7, 8].

Antibiotic resistance has emerged as a major public health threat in India. A high burden of infectious diseases, unregulated sale of antibiotics, financial incentives for healthcare providers to prescribe antibiotics, patient expectations, rising incomes, and limited public health response have helped drive the emergence of resistance $[9,10]$. Rapid emergence of resistance among these common pathogens is posing a serious threat.

The present study is a hospital based cross sectional study to understand the prevalence of various bacterial pathogens associated with the childhood diarrhoea cases admitted/attending largest government tertiary care hospital in Odisha, India. The result obtained from this study will be helpful in identifying the prevalent bacterial pathogens associated with acute diarrhoeal disease (ADD) in children under 5 years, emerging antimicrobial resistance trends and formulate interventional strategies for effective management and control of ADD in under five children.

\section{Methods}

Patients and samples

Childhood diarrhoea cases ( $\leq 5 \mathrm{yrs}$ ) who were either attending or admitted the SCB Medical College (largest government-run medical college and hospital in Odisha) during 1st September, 2015 to 30th November 2017 were included in the study. After obtaining signed consent, stool samples were collected and processed for the isolation and identification of causative agent.

\section{Microbiological examination}

The stool samples were subjected to standard techniques for isolation and identification of the bacterial isolates using suitable growth media [11]. After overnight incubation at $37^{\circ} \mathrm{C}$, a single colony was isolated from the selective media and grown in pure culture and subsequently identified using standard procedure in which the suspected colonies were subjected to biochemical and serological tests for Vibrio sp., Shigella sp. and Salmonella enterica sp. using group-specific antisera (Denka Seiken Co., Ltd., Tokyo, Japan). Wherever more than a single type of colony was observed, all the suspected colonies were subjected to isolation and identification. The E. coli isolated on culture plate from a diarrhoea stool were subjected to PCR based identification and pathotyping.

\section{Antimicrobial resistance profiling}

Antibiotic sensitivity tests were performed by a disk diffusion method for 11 drugs (Amikacin AMK; Cotrimoxazole, CoT; Imipenem, IPM; Tetracycline, TET; Nalidixic acid, NAL; Ofloxacin, OFX; Ciprofloxacin, CIP; Levofloxacin, LEV; Ceftriaxone, CRO; Ampicillin, AMP; Amoxicillin/clavulanic acid, AMC) following the Clinical and Laboratory Standards Institute (CLSI) guidelines, 2015 [12]. Control strains of Escherichia coli ATCC 25922 and Staphylococcus aureus ATCC 25923 were included in each test. Multi-drug resistance was defined as resistant to 3 or more antimicrobial categories [13].

\section{ESBL production}

The isolates exhibiting resistance to to third-generation cephalosporins were tested for the production of extended spectrum $\beta$-lactamase (ESBL) using the combination disk test with ceftazidime-clavulanic acid (CAC, $30 / 10 \mu \mathrm{g})$ and ceftriaxone-clavulanic acid $[11,13]$.

\section{Minimum inhibitory concentrations}

Etest (AB Biodisk, Solna, Sweden) was used for detection of minimum inhibitory concentrations (MICs) for quinolones (NAL) and fluoroquinolones (CIP and OFX), which was interpreted as per the CLSI guidelines [11].

\section{Detection of diarrhoeagenic E.coli by multiplex PCR}

DNA was isolated following the heat-chill method [14]. The template DNA was used in PCR for detection of various DEC like Enterotoxigenic E.coli (ETEC), Enteropathogenic E.coli (EPEC), Enteroaggregative E.coli (EAEC) and Enterohemorrhagic E.coli (EHEC) [15]. The isolates 
were screened for various virulent genes specific for ETEC (elt, est), EPEC (bfpA, eae), EAEC (aatA, aaiC) and EHEC (stx1, stx2) using standard procedure (Table 1). The

Table 1 PCR primers used in the study

\begin{tabular}{|c|c|c|c|}
\hline Gene & Sequence $\left(5^{\prime}-3^{\prime}\right)$ & $\begin{array}{l}\text { Annealing } \\
\text { temp }\left({ }^{\circ} \mathrm{C}\right)\end{array}$ & $\begin{array}{l}\text { Amplicon } \\
\text { size (bp) }\end{array}$ \\
\hline \multirow[t]{2}{*}{ elt } & CACACGGAGCTCCTCAGTC & 57 & 508 \\
\hline & CCCCCAGCCTAGCTTAGTTT & & \\
\hline \multirow[t]{2}{*}{ est } & GCTAAACCAGTAG/AGGTCTTCAAAA & 57 & 147 \\
\hline & CCCGGTACAG/AGCAGGATTACAACA & & \\
\hline \multirow[t]{2}{*}{ bfpA } & GGAAGTCAAATTCATGGGGG & 57 & 367 \\
\hline & GGAATCAGACGCAGACTGGT & & \\
\hline \multirow[t]{2}{*}{ AatA } & CTGGCGAAAGACTGTATCAT & 57 & 630 \\
\hline & CAATGTATAGAAATCCGCTGTT & & \\
\hline \multirow[t]{2}{*}{ eae } & CCCGAATTCGGCACAAGCATAAGC & 57 & 881 \\
\hline & CCCGGATCCGTCTCGCCAGTATTCG & & \\
\hline \multirow[t]{2}{*}{ aaic } & ATTGTCCTCAGGCATTTCAC & 57 & 215 \\
\hline & ACGACACCCCTGATAAACAA & & \\
\hline \multirow[t]{2}{*}{ Stx 1} & CAACACTGGATGATCTCAG & 57 & 350 \\
\hline & СССССТСААСТGСТАATA & & \\
\hline \multirow[t]{2}{*}{ Stx2 } & ATCAGTCGTCACTCACTGGT & 57 & 110 \\
\hline & CTGCTGTCACAGTGACAAA & & \\
\hline \multirow[t]{2}{*}{ bla $a_{C T X-M 3}$} & AATCACTGCGTCAGTTCAC & 50 & 701 \\
\hline & TTTATCCCCCACAACCCAG & & \\
\hline \multirow[t]{2}{*}{ NDM-1 } & ACCGCCTGGACCGATGACCA & 58 & 264 \\
\hline & GCCAAAGTTGGGCGCGGTTG & & \\
\hline \multirow[t]{2}{*}{ gyrA } & TACACCGGTCAACATTGAGG & 64 & 648 \\
\hline & TTAATGATTGCCGCCGTCGG & & \\
\hline \multirow[t]{2}{*}{ gyrB } & TGAAATGACCCGCCGTAAAGG & 64 & 309 \\
\hline & GCTGTGATAACGCAGTITGTCCGGG & & \\
\hline \multirow[t]{2}{*}{ parc } & GTCTGAACTGGGCCTGAATGC & 64 & 249 \\
\hline & AGCAGCTCGGAATATTTCGACAA & & \\
\hline \multirow[t]{2}{*}{ parE } & ATGCGTGCGGCTAAAAAAGTG & 64 & 290 \\
\hline & TCGTCGCTGTCAGGATCGATAC & & \\
\hline \multirow[t]{2}{*}{ qnrA } & ATTTCTCACGCCAGGATTTG & 64 & 516 \\
\hline & GATCGGCAAAGGTTAGGTCA & & \\
\hline \multirow[t]{2}{*}{ anrB } & GATCGTGAAAGCCAGAAAGG & 64 & 476 \\
\hline & ATGAGCAACGATGCCTGGTA & & \\
\hline \multirow[t]{2}{*}{ anrC } & GGGTTGTACATTTATTGAATCG & 64 & 307 \\
\hline & СACCTACCCATTTATTTTCA & & \\
\hline \multirow[t]{2}{*}{ anrs } & GCAAGTTCATTGAACAGGGT & 64 & 428 \\
\hline & TCTAAACCGTCGAGTTCGGCG & & \\
\hline \multirow[t]{2}{*}{$\operatorname{aac}\left(6^{\prime}\right)-1 b-c r$} & TTGCGATGCTCTATGAGTGGCTA & 55 & 482 \\
\hline & CTCGAATGCCTGGCGTGTTT & & \\
\hline \multirow[t]{2}{*}{ qерА } & AACTGCTTGAGCCCGTAGAT & 55 & 596 \\
\hline & GTCTACGCCATGGACCTCAC & & \\
\hline
\end{tabular}

strains harboring these particular genes were considered positive for the respective strains of DEC. DNA from previously confirmed strains belonging to the 4 types of DEC were included in each PCR assay as positive control. Sterile double distilled water was used as negative control.

\section{Mutation analysis in QRDRs}

The quinolone resistance determining regions (QRDRs) of the $\operatorname{gyr} A$, gyrB, parC, and parE genes were amplified using published primers (Table 1), as reported previously [16]. Positive and negative control was used to establish the validity of the PCR assay. PCR products were then sequenced in an automatic sequencer (ABI 3130; Applied Biosystems, Foster City, CA, USA) followed by detection of mutation using SeqScape v3 (ABI 3130; Applied Biosystems).

\section{Screening of the PMQR determinants}

The plasmid mediated quinolone resistance (PMQR) determinants which includes qnr determinants $q n r A$, qnrB, $q n r C$, qnrS, and two additional genes, $a a c\left(6^{\prime}\right)-I b-c r$ and qepA were screened for quinolone resistant strains using published primers (Table 1) $[17,18]$.

\section{Screening for the presence of NDM-1 gene}

PCR based detection of NDM-1 was performed for all strains resistant to Imipenem using published primers [19]. DNA isolated from previously isolated confirmed NDM-1 strain of P.putida was used as positive control and sterile distilled water was used as negative control to establish the validity of the PCR assay.

\section{Statistical data analysis}

Data was analysed statistically by SPSS version 21 software. Test used was Pearson chi square and chi square with Yates correction. $p$ value $<0.05$ was considered significant.

\section{Results}

Patients and isolates

During the study, 320 patients were enrolled and sample were collected and processed from them, which includes 157 (49.06\%) male and 163 (50.94\%) female (Table 2). Bacteriological examination, revealed, 82 bacterial isolates from these samples, giving a proportional causality for bacterial diarrhoea of $25.6 \%$ among children in this region. No coinfection was observed. Each bacterial isolate was obtained from different individual cases i.e., 82 isolates were obtained from 82 different individual cases. The number of cases as well as isolation of bacterial pathogens were high during Sept-Oct during the 2 years period (Fig. 1). No deaths due to bacterial diarrhoea were reported during the study period. Of these 82 bacterial isolates, 77 (24\%) were DEC, $2(0.6 \%)$ were V. cholerae, 2 $(0.6 \%)$ were S. flexneri, and $1(0.3 \%)$ were Salmonella enterica Paratyphi B. PCR based identification of DEC 
Table 2 Prevalence of DEC pathotypes among the age group

\begin{tabular}{|c|c|c|c|c|c|c|c|}
\hline \multirow[t]{2}{*}{ DEC } & \multirow[t]{2}{*}{ Total } & \multicolumn{5}{|c|}{ Age (in months) } & \multirow{2}{*}{$\begin{array}{l}\text { Overall } 2 \\
\text { values }^{\mathrm{a}}\end{array}$} \\
\hline & & $0-6$ & $7-24$ & $25-36$ & $37-48$ & $49-60$ & \\
\hline ETEC-LT & $13(16.9)$ & 0 & $1(33.3)$ & $1(20.0)$ & $9(15.0)$ & $2(25.0)$ & 20.312188 \\
\hline ETEC-ST & $17(22.1)$ & 0 & $1(33.3)$ & 0 & $16(26.7)$ & 0 & 1.766234 \\
\hline ETEC-LT + ST & $10(12.9)$ & 0 & $1(33.3)$ & $1(20.0)$ & $5(8.3)$ & $3(37.5)$ & 33.701461 \\
\hline aEPEC & $19(24.7)$ & 0 & 0 & $2(40.0)$ & $16(26.7)$ & $1(12.5)$ & 10.480605 \\
\hline tEPEC & $14(18.2)$ & 0 & 0 & $1(20.0)$ & $12(20)$ & $1(12.5)$ & 10.142045 \\
\hline EAEC & $4(5.2)$ & $1(100)$ & 0 & 0 & $2(3.3)$ & $1(12.5)$ & 10.821834 \\
\hline Total & 77 & 1 & 3 & 5 & 60 & 8 & 87.22436 \\
\hline
\end{tabular}

${ }^{a}$ at $10 \%$ level of significance

revealed, 40 (51.9\%) as ETEC, $33(42.8 \%)$ as EPEC and 4 (5.1\%) as EAEC.

\section{Pathotypes of DEC}

Among the 77 DEC detected from 320 cases, 40 (51.9\%) were identified as ETEC, $33(42.8 \%)$ as EPEC and 4 (5.1\%) as EAEC by PCR based detection of toxigenic genes (Table 2). ETEC with elt was higher than est. ETEC in the age group of 25-26 years and 49-60 years, however its was lower in the age group of 37-48 years. Prevalence of atypical EPEC (aEPEC) was found to be more than typical EPEC (tEPEC), however the difference was not statistically significant although overall prevalence of DEC pathotypes were statistically significant at $10 \%$.

\section{Age-wise distribution}

The patients were categorized into 5 age groups viz. 0 $6,7-24,25-36,37-48$ and $49-60$ months to understand the distribution of various pathogens among these age. The cases (30.6\%; 98 of 320 ) as well as isolates (76.82\%; 63 of 82) were found to be highest in the age group of 37-48 months (Table 3, Fig. 1).

\section{Clinical features}

Mucous stool, abdominal pain, anaemia, vomiting, fever, and severe dehydration, were found to be associated with the patients enrolled (Table 3). Significant difference was not observed among these clinical presentations between total cases and isolation positive cases. Most of the DEC cases were associated with diarrhoea for more than 3 days. No significant difference was observed among the clinical features associated among the samples positive for bacterial isolation and negative except in case of duration of diarrhoea (3-6 days) and dehydration (Table 3).

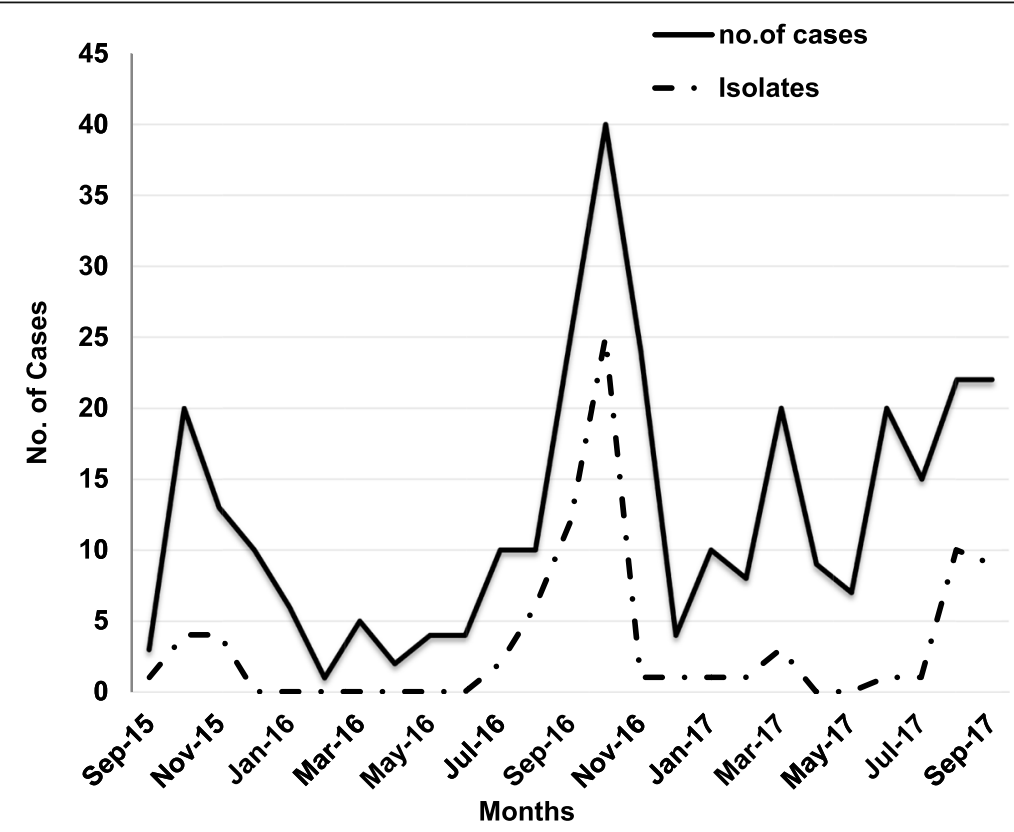

Fig. 1 Seasonal pattern of distribution of acute diarrhoeal cases and pathogenic isolates 
Table 3 Basic information and clinical symptoms of the children with acute diarrhoea cases and isolation positive cases

\begin{tabular}{|c|c|c|c|c|c|}
\hline \multicolumn{2}{|l|}{ Characteristics } & \multirow{2}{*}{$\begin{array}{l}\text { Total } \\
\text { cases (\%) } \\
N=320\end{array}$} & \multirow{2}{*}{$\begin{array}{l}\text { Negative for bacterial } \\
\text { isolation (\%) } \\
n=238\end{array}$} & \multirow{2}{*}{$\begin{array}{l}\text { Positive for bacterial } \\
\text { isolation (\%) } \\
n=82\end{array}$} & \multirow[t]{2}{*}{$p$ value } \\
\hline Age (in months) & & & & & \\
\hline $0-6$ & & $10(3.1)$ & $9(3.8)$ & $1(1.2)$ & 0.250 \\
\hline $7-24$ & & $78(24.4)$ & 75 (31.5) & $3(3.7)$ & 0.000 \\
\hline $25-36$ & & $74(23.1)$ & $68(28.5)$ & $6(7.3)$ & 0.000 \\
\hline $37-48$ & & 98 (30.6) & $35(14.7)$ & 63(76.8) & 0.000 \\
\hline $49-60$ & & $60(18.8)$ & $51(21.4)$ & $9(10.9)$ & 0.036 \\
\hline \multirow[t]{2}{*}{ Sex } & Male & $157(49.06)$ & $123(51.6)$ & $34(41.5)$ & 0.110 \\
\hline & Female & $163(50.94)$ & 115(48.3) & $48(58.5)$ & 0.110 \\
\hline \multirow[t]{3}{*}{ Duration of diarrhoea } & $<3$ days & $61(19.1)$ & $48(20.1)$ & $13(15.9)$ & 0.391 \\
\hline & $3-6$ days & $176(55.0)$ & $108(45.3)$ & $68(82.9)$ & 0.000 \\
\hline & $>6$ days & $1(0.3)$ & 0 & $1(1.2)$ & - \\
\hline Fever & $37-39^{\circ} \mathrm{C}$ & 138(43.1) & $107(44.9)$ & $31(37.8)$ & 0.259 \\
\hline Vomiting & & 115(35.9) & 91 (38.2) & $24(29.3)$ & 0.144 \\
\hline Dehydration & & $33(10.3)$ & $16(6.2)$ & $17(20.7)$ & 0.000 \\
\hline Anaemia & & $21(6.5)$ & $13(5.6)$ & $8(9.6)$ & 0.175 \\
\hline Abdominal Pain & & 127(39.6) & 89 (37.3) & $38(46.3)$ & 0.153 \\
\hline
\end{tabular}

\section{Antibiotic sensitivity among bacterial isolates}

A wide range of antibiotic resistance was observed among the bacterial isolates with more than $50 \%$ of the isolates resistant to more than $50 \%$ of the drugs tested (Table 4). All the $82(100 \%)$ isolates were multidrugresistant. More than $60 \%$ of the DEC were resistant to CRO (3rd generation Cephalosporins) and Fluoroquinolones (OFX and CIP). Among the 49 strains resistant to CRO, only 3 isolates of EPEC showed the presence ESBL production of which all are aEPEC. All these 3 isolates harbored the CTX-M3 gene. Among the 82 isolates, 2 (2.4\%) DEC showed the resistance to Imipenem, one harbored carbapenemase gene NDM-1.

\section{Fluoroquinolone resistance among the bacterial strains}

All the bacterial isolates were resistant to nalidixic acid of which 11 were sensitive to the fluoroquinolones (FLQ). A total of 59 (71.9\%) of strains were ciprofloxacin resistant and 48 (58.5\%) were ofloxacin resistant respectively (Table 3 ). Minimum inhibitory concentration of the isolates ranged between 64 to $>256 \mu \mathrm{g} / \mathrm{mL}$ for nalidixic acid, 4 to $>256 \mu \mathrm{g} / \mathrm{mL}$ for ciprofloxacin and 16 to $>256 \mu \mathrm{g} / \mathrm{mL}$ for ofloxacin.

\section{Detection of mutation in QRDR region and screening of PMQR}

Only 20 DEC isolates resistant to quinolones and fluoroquinolones were subjected to QRDR mutation and screening of PMQR, which include 5 NAL resistant and 15 FLQ resistant strains. Several mutations were detected in the QRDR region of the fluoroquinolone resistant E.coli isolates (Table 5).

All the 5 quinolone (nalidixic acid) resistant strains had a single mutation in gyrA at amino acid position 83 (replacement of serine with leucine). All the 15 FLQ resistant strains had double mutations at amino acid position 83 (replacement of serine with leucine) and D87N (replacement of aspartic acid with asparagine) (Table 5). Out of 15 FLQ resistant strains tested, eight resistant strains had a single mutation in parC at amino acid position S80I (replacement of serine with isoleucine). No mutation was detected in nucleotide sequences of $\operatorname{gyr} B$ and parC region. Only one isolate harbored both $q n r B$ and aac6'Ibcr genes.

\section{Discussion}

Diarrhoea is the third leading cause of childhood mortality in India, and is responsible for $13 \%$ of all deaths/year in

Table 4 Antibiotic resistance pattern of the bacterial isolates obtained during the study period

\begin{tabular}{|c|c|c|c|c|c|c|c|c|c|c|c|c|}
\hline Organism & $\begin{array}{l}\text { No of pathogenic } \\
\text { organism (\%) } n=82\end{array}$ & AMK & CoT & IMP & TET & NAL & OFX & $\mathrm{CRO}$ & AMP & LEV & AMC & CIP \\
\hline DEC & 77 (94) & 1 & $45(61)$ & 2 & $18(28.1)$ & 77 (100) & 47 (61.1) & $49(63.7)$ & 66 (86.6) & $43(55.9)$ & $34(44.2)$ & $56(74.4)$ \\
\hline S. flexneri & 2 & $0(0)$ & $0(0)$ & $0(0)$ & 1 & 2 & 1 & 1 & 2 & 2 & 2 & 2 \\
\hline Salmonella Paratyphi B & 1 & $0(0)$ & $0(0)$ & $0(0)$ & $0(0)$ & 1 & $0(0)$ & $0(0)$ & 1 & $0(0)$ & 1 & $0(0)$ \\
\hline V.cholerae 01 & 2 & $0(0)$ & 2 & $0(0)$ & $0(0)$ & 2 & $0(0)$ & $0(0)$ & 1 & 1 & 1 & 1 \\
\hline
\end{tabular}


Table 5 Mutations in the QRDR region of the DEC isolates

\begin{tabular}{|c|c|c|c|c|c|c|c|c|c|c|c|}
\hline \multirow{2}{*}{$\begin{array}{l}\text { SI } \\
\text { No. }\end{array}$} & \multirow{2}{*}{$\begin{array}{l}\text { Strain } \\
\text { No. }\end{array}$} & & \multirow{2}{*}{$\begin{array}{l}\text { ABST for } \\
\text { Quinolone }\end{array}$} & \multicolumn{3}{|c|}{$\mathrm{MIC}(\mu \mathrm{g} / \mathrm{ml})$} & \multirow{2}{*}{$\begin{array}{l}\text { gyrA } \\
\text { S83-L }\end{array}$} & \multirow{2}{*}{$\begin{array}{l}\text { parC } \\
\text { D87-N }\end{array}$} & \multirow{2}{*}{$\begin{array}{l}\text { qnrB } \\
\text { S80-I }\end{array}$} & \multicolumn{2}{|c|}{$a a c \sigma^{\prime} \mid b c r$} \\
\hline & & & & $\overline{N A L}$ & CIP & OFX & & & & & \\
\hline 1 & DEC1 & ETEC & NAL & 128 & - & - & + & - & - & - & - \\
\hline 2 & DEC2 & ETEC & NAL & 256 & - & - & + & - & - & - & - \\
\hline 3 & DEC3 & ETEC & NAL & 128 & - & - & + & - & - & - & - \\
\hline 4 & DEC4 & aEPEC & NAL & 64 & - & - & + & - & - & - & - \\
\hline 5 & DEC5 & EAEC & NAL & 128 & - & - & + & - & - & - & - \\
\hline 6 & DEC6 & aEPEC & NAL,CIP, OFX & $>256$ & 128 & 32 & + & + & + & - & - \\
\hline 7 & DEC7 & ETEC & NAL,CIP, OFX & $>256$ & 64 & 64 & + & + & + & - & - \\
\hline 8 & DEC8 & aEPEC & NAL,CIP & $>256$ & 4 & - & + & + & - & - & - \\
\hline 9 & DEC9 & ETEC & NAL,CIP, OFX & $>256$ & $>256$ & $>256$ & + & + & + & + & + \\
\hline 10 & DEC10 & tEPEC & NAL,CIP, OFX & $>256$ & 64 & 32 & + & + & + & - & - \\
\hline 11 & DEC11 & ETEC & NAL,CIP, OFX & $>256$ & 32 & 32 & + & + & + & - & - \\
\hline 12 & DEC12 & EAEC & NAL, OFX & 128 & - & 4 & + & + & - & - & - \\
\hline 13 & DEC13 & ETEC & NAL,CIP & 64 & 16 & - & + & + & - & - & - \\
\hline 14 & DEC14 & aEPEC & NAL,CIP, OFX & $>256$ & 128 & 32 & + & + & + & - & - \\
\hline 15 & DEC15 & tEPEC & NAL,CIP, OFX & $>256$ & 32 & 32 & + & + & + & - & - \\
\hline 16 & DEC16 & tEPEC & NAL,CIP, OFX & $>256$ & 128 & 128 & + & + & + & - & - \\
\hline 17 & DEC17 & ETEC & NAL,CIP & $>256$ & $>256$ & - & + & + & - & - & - \\
\hline 18 & DEC18 & aEPEC & NAL,OFX & $>256$ & - & $>256$ & + & + & - & - & - \\
\hline 19 & DEC19 & ETEC & NAL,CIP & $>256$ & 128 & - & + & + & - & - & - \\
\hline 20 & DEC20 & ETEC & $\mathrm{NAL}, \mathrm{CIP}$ & $>256$ & 64 & - & + & + & - & - & - \\
\hline
\end{tabular}

children under 5 years of age [3]. The clinico-observational study was conducted from September, 2015 to November 2017 to identify the potential bacterial pathogens responsible for childhood diarrhoea ( $\leq 5$ years), drug resistance pattern, genetic markers of virulence and mutation in chromosomal gene. In the present study, 320 non-repeat stool samples from acute diarrhoeal cases were collected and processed for isolation of any bacterial pathogen. Of the 320 diarrhoea cases tested, 157 were from male children, which was lower than detected from females (163), giving a male to female ratio of $0.9: 1$, lightly different than reported elsewhere [20].

The age and gender wise distribution pattern in 320 children were studied. Most children belonged to 37-48 months of age (30.6\%), followed by 7-24 months (24.37\%). Mean age of distribution was (Mean \pm SD) $34.99 \pm 12.77$ months, which is concordant with other studies [21-23]. Saeed et al [20] reported maximum number of diarrhoea cases in 49 to 60 months age group (66\%), followed by 37 to 48 months of age group (18\%). In contradiction to earlier reports [13], the current study reports the majority of diarrhoea cases (72.5\%) as well as positive samples (95\%) in the age group older than 2 years, particularly those in the age group of 3-5 years as noted above.

The present study, demonstrates a proportional causality for bacterial diarrhoea of $25.6 \%$ among under five children in these region among children suffering from gastroenteritis, which is similar to study in other geographical region [24]. Although the morbidity due to bacterial enteric pathogens detected in the current study was low but it was similar to other reports from elsewhere [7, 13, 15, 24]. Moreover, the facility where the study was carried out was a tertiary care hospital and catering services to referred cases from primary and secondary healthcare facilities which might have resulted in low bacterial isolation rate. The current study revealed, majority of acute diarrhoeal cases were associated with common signs and symptoms i.e. fever (52.7\%) followed by abdominal pain $(51.4 \%)$, vomiting $(43.4 \%)$, dehydration $(15.6 \%)$ and anemia (9\%) similar to study by Raghavan et al [20] who reported fever in $57.9 \%$ followed by vomiting in $56.8 \%$ cases.

Our current study in accordance with previous other studies [20, 21, 23] revealed, amongst pathogenic isolates, diarrhoeagenic Escherichia coli (DEC) was the most common isolate, 77 (24\%), followed by Shigella flexneri (0.6\%), Vibrio cholerae (0.6\%) and Salmonella paratyphi $B(0.3 \%)$.

Majority of studies showed that E.coli as the most important etiological agents of childhood diarrhoea and represents a major public health problem in developing [20]. Among the hospitalized diarrhoeal children up to 
5 years of age, DEC was high next to rotavirus and in patients more than 5 years; DEC-mediated diarrhoeal infection was positioned next to cholera [25]. Prevalence of DEC in this study was almost $24 \%$ which is higher than the other reports from developing countries and other parts of India [13, 26-29] suggesting variation in distribution of DEC based on geographical location. Among DEC, Enterotoxigenic E.coli was found to be 40 (51.9\%), Enteropathogenic E.coli in 33 (42.8\%) and Enteroagrregative E.coli in 4 (5.1\%). Although EPEC, has been described as the most frequent DEC pathotype in many developing countries [13], our study revealed ETEC as the most prevalent DEC isolated followed by EPEC and EAEC which highlights the need for continued surveillance to understand in depth the distribution pattern. The diarrhoea produced by ETEC is of the secretory type: the disease begins with a sudden onset of watery stool (without blood or inflammatory cells) and often vomiting, which lead to dehydration from the loss of fluids and electrolytes [13,30].

As observed previously [26], the present study also revealed that the infections caused by elt harbouring ETEC strains was less compared to est harbouring ETEC. In accordance to earlier studies [26,31] aEPEC was found to be more than tEPEC across all age group.

In the present study, in comparison to other studies [15] the prevalence of other bacterial pathogens like Shigella sp., Salmonella enterica and V.cholerae O1 were relatively lower. However, all these bacterial pathogens isolated belonging to these species were multi-drug resistant.

Most of the bacterial pathogen isolated were multidrug resistant which include resistance to ampicillin (85.3\%) followed by ciprofloxacin (70.7\%), ceftriaxone (60.9\%), ofloxacin (58.5\%), cotrimoxazole (57.3\%) and levofloxacin (56.1\%). The rate of resistance among Diarrhoegenic E.coli to 1st line, 2nd line and 3rd line of therapeutic drugs were equally high. Earlier studies carried out in the different parts of the world also showed the emergence of MDR among enteric pathogens [12, 21, 23, 32]. Majority of the isolates were sensitive to amikacin, imipenem and tetracycline. In the current study the Salmonella isolate exhibited resistance towards nalidixic acid but sensitive to ciprofloxacin. However, in the past decade there have been reports of treatment failures using fluoroquinolones in patients with typhoid fever and the isolate being susceptible to fluoroquinolones and resistant to nalidixic acid in vitro [33]. Studies have reported that plasmidmediated resistance showed reduced susceptibility to ciprofloxacin (MIC of $0.125-1.0 \mu \mathrm{g} / \mathrm{ml}$ ), which could not be picked up by the nalidixic acid test [34]. However, the mechanism is not well understood.

In our study, $62.3 \%$ of DEC isolates were ESBL producers which is similar earlier report [35]. The ESBL producing strains showed complete resistance to ampicillin and cephalosporins. This kind of antibiotic resistance pattern might be because of early institution of antimicrobial therapy leading to prevalence of resistant strains [36]. Polymerase chain reaction (PCR) was used to detect CTX$M 3$ gene, known as one of the factor for ESBL production. In present study, only $3(6.1 \%)$ isolates were positive for blaCTX-M3 gene, which is less in comparison to earlier reports [32, 37] suggesting possible role of other $\beta$ lactamase genes resistance development, which needs to be studied further. During the study period, all the 82 bacterial isolates were resistant nalidixic acid resistant, 59 (71.9\%) strains were ciprofloxacin resistant and 48 (58.5\%) were ofloxacin resistant. Minimum inhibitory concentration of the isolates ranged between 64 to $>256 \mu \mathrm{g} / \mathrm{mL}$ for nalidixic acid, 4 to $>256 \mu \mathrm{g} / \mathrm{mL}$ for ciprofloxacin and 16 to $>256 \mu \mathrm{g} / \mathrm{mL}$ for ofloxacin.

A subset of DEC isolates resistant to quinolones and fluoroquinolones were subjected to screening for QRDR mutation. Mutations were detected in the gyrA and parC region of the QRDR. No mutation was detected in nucleotide sequences of gyrB and parE region. Only one isolate harboured both $q n r B$ and $a a c\left(6^{\prime}\right)-I b-c r$ genes. This isolate showed high values of MIC for ciprofloxacin and ofloxacin. Aac(6')-Ib-cr gene, a variant of the common aminoglycoside acetyltransferase is capable of acetylating the piperazinyl substituent of some fluoroquinolones [38], thereby reducing their activities. Similar to earlier reports $[32,39]$, the present study also detected that quinolone and fluoroquinolone resistance is linked mainly to mutations located in the QRDRs of DNA gyrase (GyrA and GyrB) and topoisomerase IV (ParC and ParE). Current study also supports the previous report [17] of PMQR being a stepwise phenomenon following the multiple mutations in QRDR region.

Carbapenems are recommended as the first option to treat ESBL-resistant strains, however the present study detected emergence of carbapenem resistance among the DEC (2.4\%) strains which calls for continuous monitoring to decide the empirical treatment strategy for these common pathogens. Carbapenem resistance in the Enterobacteriaceae is mainly attributed to the production of carbapenemases and the mot predominant being the $b l a_{N D M-1}$. The present report to the best of our knowledge is the 1st report of presence of $N D M-1$ in any pathogen from the state of Odisha.

\section{Conclusion}

Knowledge on the etiology is important for effective management and control of diarrhoea. The current study, to the best of our knowledge is first of its kind which demonstrated the etiology of bacterial diarrhoea in children and molecular mechanism of resistance development in Odisha. The present study shows that diarrheogenic $E$. coli are the predominant enteropathogen 
causing diarrhoea in children less than five years old with majority of the isolates being multi-drug resistance. Emergence of ESBL and carbapenem resistance was also observed among the DEC strains. The data calls for a continuous surveillance system to identify the etiological agents causing diarrhoea which will be instrumental in identifying emerging antimicrobial resistance and for developing treatment guidelines and intervention strategies appropriate for the community.

\section{Abbreviations}

ADD: Acute diarrhoeal disease; aEPEC: Atypical EPEC; DEC: Diarrhoegenic E.coli; EAEC: Enteroaggregative E.coli; EHEC: Enterohemorrhagic E.coli; EPEC: Enteropathogenic E.coli; ESBL: Extended spectrum $\beta$-lactamase; ETEC: Entero toxigenic E.coli; IMNCI: Immunization and Integrated Management of Childhood illnesses; NDM-1: New Delhi metallo $\beta$ lactamase1; PMQR: Plasmid mediated quinolone resistance; QRDR: Quinolone resistance determining regions; tEPEC: typical EPEC

\section{Acknowledgements}

The authors are also thankful to all the subjects for their participation in the study.

\section{Authors' contributions}

DB designed the study. SSM, RKP, MD and NC were responsible for recruitment and interview of the patients. DB, SSM and PB were responsible for samples collection, transport to the laboratory and laboratory procedures. SSM and RKP did the statistical analysis. DB, SSM, NC and SP wrote the manuscript. All authors have read and approved the final manuscript.

\section{Funding}

The study did not receive any extramural grant/funding from any source and was supported by the intramural funds of the centre. The funding body had no role in the design of the study and collection, analysis, and interpretation of data and in writing the manuscript.

\section{Availability of data and materials}

The datasets used and/or analyzed during the current study are available from the corresponding author on reasonable request.

\section{Ethics approval and consent to participate}

The study was cleared by Institutional Human Ethical Committee of ICMRRegional Medical Research Centre, Bhubaneswar. Informed written consent was obtained from the parents or legal guardian of the patient before inclusion in the study.

\section{Consent for publication}

Not applicable.

\section{Competing interests}

The authors declare that they have no competing interests.

\section{Author details}

'Dept. of Microbiology, SCB Medical College (Govt. of Odisha), Manglabag, Cuttack, Odisha 753007, India. ${ }^{2}$ Dept. of Bacteriology \& One Health, ICMR-Regional Medical Research Centre (Dept. of Health Reserch, Ministry of Health \& Family Welfare, Govt. of India), Chandrasekharpur, Bhubaneswar 751023, India.

Received: 23 November 2018 Accepted: 24 September 2019

Published online: 02 December 2019

\section{References}

1. Kosek M, Bern C, Guerrant R. The global burden of diarrhoeal disease, as estimated from studies published between 1992 and 2000. Bull World Health Organ. 2003;81:197-204.

2. Bhan MK. Accelerated progress to reduce under-5 mortality in India. Lancet Glob Health. 2013;1:e172-3.
3. Lakshminarayanan S, Jayalakshmy R. Diarrhoeal diseases among children in India: current scenario and future perspectives. J Nat Sci Biol Med. 2015;6(1):24-8.

4. Estimation of the Burden of Diarrhoeal diseases in India, NICED Kolkata available from http://www.whoindia.org/linkfiles/commission on macroeconomic and health Bg P2 Estimation of the burden of diarrhoeal diseases in India.pdf.

5. Verma S, Kumar V, Singh P. Managing childhood diarrhoea at homes in India: an opportunity to reduce child morbidity and mortality. Australasian College for Infection Prevention and Control. 2016;21(4):176-83.

6. Foodborne IIIness acquired in United states. https://wwwnc.cdc.gov/eid/ article/17/1/p1-1101_article. Last

7. Vu Nguyen T, Le Van P, Le Huy C, Nguyen Gia K, Weintraub A. Etiology and epidemiology of diarrhoea in children in Hanoi, Vietnam. Int J Infect Dis. 2006:10:298-308.

8. Zaidi AKM, Awasthi S, DeSilva HJ. Burden of infectious diseases in South Asia. BMJ. 2004:328:811-5.

9. Laxminarayan R, Chaudhury RR. Antibiotic resistance in India: drivers and opportunities for action. PLoS Med. 2016;13(3):e1001974.

10. Kakkar M, Walia K, Vong S, Chatterjee $P$, Sharma A. Antibiotic resistance and its containment in India. BMJ. 2017;358:j2687.

11. World Health Organization. Manual for laboratory investigation of acute enteric infections. CDD/83.3. WHO, Geneva, Switzerland. 1987.

12. Clinical and Laboratory Standards Institute. Performance standards for antimicrobial susceptibility testing, twenty-fifth informational supplement, M100-S25. Wayne, PA: Clin Lab Stand Institute; 2015.

13. Zhou Y, Zhu X, Hou H, Lu Y, Yu J, Mao L, Mao L, Sun Z. Characteristics of diarrhoeagenic Escherichia coli among children under 5 years of age with acute diarrhoea: a hospital-based study. BMC Infect Dis. 2018;18:63.

14. Bhattacharya D, Sugunan AP, Bhattacharjee $H$, Thamizhmani $R$, Sudharama SD, Manimunda SP, et al. Rapid emergence of third-generation cephalosporin resistance in Shigella sp. isolated in Andaman and Nicobar Islands, India. Microb Drug Resist. 2011;17:329-32.

15. Purwar S, Bhattacharya D, Metgud SC, Kumar D, Chitambar SD, Roy S. A cross-sectional study on aetiology of diarrhoeal disease, India. Indian J Med Microbiol. 2016:34(2):101-5.

16. Dutta S, Kawamura Y, Ezaki T, Nair GB, lida K, Yoshida S. Alteration in the GyrA subunit of DNA gyrase and the ParC subunit of topoisomerase IV in quinolone-resistant Shigella dysenteriae serotype 1 clinical isolates from Kolkata, India. Antimicrob Agents Chemother. 2005:49:1660-1.

17. Bhattacharya D, Bhattacharjee $H$, Thamizhmani R, Sayi DS, Bharadwaj AP, Singhania $M$, et al. Prevalence of the plasmid-mediated quinolone resistance determinants among clinical isolates of Shigella sp. in Andaman \& Nicobar Islands, India. Lett Appl Microbiol. 2011;53(2):247-51.

18. Kim HB, Park CH, Kim CJ, Kim EC, Jacoby GA, Hooper DC. Prevalence of plasmid-mediated quinolone resistance determinants over a 9-year period. Antimicrob Agents Chemother. 2009;53:639-45.

19. Bhattacharya D, Thamizhmani R, Bhattacharya H, Sayi DS, Muruganandam N, Roy $\mathrm{S}$, et al. Emergence of New Delhi metallo- $\beta$-lactamase 1 (NDM-1) producing and multidrug resistant uropathogens causing urinary tract infections in Andaman Islands, India. Microb Drug Resist. 2013;19(6):457-62.

20. Saeed A, Abd H, Sandstrom G. Microbial aetiology of acute diarrhoea in children under five years of age in Khartoum, Sudan. J Med Microbiol. 2015; 64:432-7.

21. Raghavan RP, Roy S, Thamizhmani R, Sugunan AP. Diarrhoeagenic Escherichia coli infections among the children of Andaman Islands with special reference to pathotype distribution and clinical profile. J Epidemiol Glob Health. 2017;7(4):305-8

22. Soli KW, Maure T, Kas MP, Bande G, Bebes S, Luang-Suarkia D, et al. Detection of enteric viral and bacterial pathogens associated with paediatric diarrhoea in Goroka, Papua New Guinea. Int J Infect Dis. 2014;27:54-8.

23. Rathaur VK, Pathania M, Jayara A, Yadav N. Clinical study of acute childhood diarrhoea caused by bacterial enteropathogens. J Clin Diagn Res. 2014;8(5): PC01-5.

24. Wang WL, Reller LB, Smallwood B, Luechtefeld NW, Blaser MJ. Evaluation of transport media for Campylobacter jejuni in human fecal specimens. J Clin Microbiol. 1983;18:803-7.

25. Nair GB, Ramamurthy T, Bhattacharya MK, Krishnan T, Ganguly S, Saha DR, et al. Emerging trends in the etiology of enteric pathogens as evidenced from an active surveillance of hospitalized diarrhoeal patients in Kolkata, India. Gut Pathog. 2010;2:4 
26. Dutta S, Guin S, Ghosh S, Pazhani GP, Rajendran K, Bhattacharya MK, et al. Trends in the prevalence of Diarrhoeagenic Escherichia coli among hospitalized Diarrhoeal patients in Kolkata, India. PLoS One. 2013;8(2):e56068.

27. Shetty VA, Kumar SH, Shetty AK, Karunasagar I, Karunasagar I. Prevalence and characterization of Diarrhoeagenic Escherichia coli isolated from adults and children in Mangalore, India. J Lab Physicians. 2012;4(1):24-9.

28. Ochoa TJ, Ecker L, Barletta F, Mispireta ML, Gil Al, Contreras C, et al. Age-related susceptibility to infection with diarrhoeagenic Escherichia coli among infants from Periurban areas in Lima, Peru. Clin Infect Dis. 2009:49:1694-702.

29. Estrada-Garcia T, Lopez-Saucedo C, Thompson-Bonilla R, Abonce M, LopezHernandez D, Santos Jl, et al. Association of diarrhoeagenic Escherichia col Pathotypes with infection and diarrhoea among Mexican children and association of atypical Enteropathogenic E. coli with acute diarrhoea. J Clin Microbiol. 2009;47:93-8.

30. Qadri F, Ann-Mari Svennerholm A, Faruque ASG, Sack BR. Enterotoxigenic Escherichia coli in developing countries: epidemiology, microbiology, clinical features, treatment, and prevention. Clin Microbiol Rev. 2005;18:465-83.

31. Canizalez-Roman A, Flores-Villasenor HM, Gonzalez-Nunez E, VelazquezRoman J, Vidal JE, Muro-Amador S, et al. Surveillance of Diarrhoeagenic Escherichia Coli strains isolated from diarrhoea cases from children, adults and elderly at northwest of Mexico. Front Microbiol. 2016;7:1924.

32. Bhattacharya D, Bhattacharya $H$, Thamizhmani R, Sayi DS, Reesu R, Anwesh M, et al. Shigellosis in bay of Bengal Islands, India: clinical and seasonal patterns, surveillance of antibiotic susceptibility patterns, and molecular characterization of multidrug-resistant Shigella strains isolated during a 6-year period from 2006 to 2011. Eur J Clin Microbiol Infect Dis. 2014;33(2):157-70.

33. Shakespeare WA, Davie D, Tonnerre C, Rubin MA, Strong M, Petti CA. Nalidixic acid-resistant Salmonella enterica serotype Typhi presenting as a primary psoas abscess: case report and review of the literature. J Clin Microbiol. 2005;43(2):996-8.

34. Balaji V, Shalini A, Dhiviya Prabaa MS, et al. Molecular characterization of intermediate susceptible Typhoidal Salmonella to ciprofloxacin and its impact. Mol Diagn Ther. 2016;20(3):213-9.

35. George EA, Sankar S, Jesudasan MV, Sudandiradoss C, Nandagopal B. Molecular characterization of CTX-M type extended Spectrum Beta lactamase producing $E$. coli isolated from humans and the environment. Indian J Med Microbiol. 2015:33(5):73-9.

36. Alikhani MY, Hashemi SH, Aslani MM, Farajnia S. Prevalence and antibiotic resistance patterns of diarrhoeagenic Escherichia coli isolated from adolescents and adults in Hamedan, Western Iran. Iran J Microbiol. 2013; 5(1):42-7.

37. Memariani M, Peerayeh SN, Salehi TZ, Mostafavi SKS. Enteropathogenic Escherichia coli strains isolated from children with diarrhoea. Jundishapur J Microbiol. 2015:8(4):e15620.

38. Robicsek A, Strahilevitz J, Jacoby GA, Macielag M, Abbanat D, Park CH, et al. Fluoroquinolone-modifying enzyme: a new adaptation of a common aminoglycoside acetyltransferase. Nat Med. 2006;12:83-8.

39. Talukder KA, Khajanchi BK, Islam MA, Dutta DK, Islam Z, Safa A, et al. Genetic relatedness of ciprofloxacin resistant Shigella dysenteriae type 1 strains isolated in South Asia. J Antimicrob Chemother. 2004:54:730-4.

\section{Publisher's Note}

Springer Nature remains neutral with regard to jurisdictional claims in published maps and institutional affiliations.

Ready to submit your research? Choose BMC and benefit from:
- fast, convenient online submission
- thorough peer review by experienced researchers in your field
- rapid publication on acceptance
- support for research data, including large and complex data types
- gold Open Access which fosters wider collaboration and increased citations
- maximum visibility for your research: over 100M website views per year
At BMC, research is always in progress.
Learn more biomedcentral.com/submissions

